\title{
Activation of NLRP3 inflammasome promotes the proliferation and migration of esophageal squamous cell carcinoma
}

\author{
SHUANG YU ${ }^{1}$, JIAN-JIAN YIN ${ }^{1}$, JIN-XIN MIAO ${ }^{2}$, SHI-GANG LI $^{1}$, CHEN-ZHENG HUANG $^{1}$, NING HUANG $^{3}$, \\ TIAN-LI FAN ${ }^{1}$, XIANG-NAN LI ${ }^{4}$, YAO-HE WANG ${ }^{5}$, SHENG-NA HAN ${ }^{1}$ and LI-RONG ZHANG ${ }^{1,6}$ \\ ${ }^{1}$ Department of Pharmacology, Basic Medical School, Zhengzhou University; \\ ${ }^{2}$ Department of Science and Technology, Henan University of Chinese Medicine, Zhengzhou, Henan 450001; \\ ${ }^{3}$ Department of Clinical Medicine, School of Medicine, Zhengzhou University; \\ ${ }^{4}$ Department of Thoracic Surgery, The First Clinical Hospital of Zhengzhou University; \\ ${ }^{5}$ National Centre for International Research in Cell and Gene Therapy, Academy of Medical Sciences, Zhengzhou University; \\ ${ }^{6}$ State Key Laboratory for Esophageal Cancer Prevention and Treatment, Zhengzhou University, \\ Zhengzhou, Henan 450052, P.R. China
}

Received April 4, 2019; Accepted January 14, 2020

DOI: $10.3892 /$ or.2020.7493

\begin{abstract}
Inflammasomes can identify endogenous danger signals as an inflammatory immune response. As the most common inflammasome, the NLR pyrin family domain containing 3 (NLRP3) inflammasome is associated with the pathogenesis of different tumors. However, the function of the NLRP3 inflammasome in esophageal cancer (EC) has rarely been reported. Herein, the expression levels of the components of NLRP3 inflammasome and Ki-67 were analyzed by immunohistochemistry. Furthermore, correlations between the NLRP3 inflammasome and Ki-67 along with the clinicopathological features of EC patients were evaluated. The components of the NLRP3 inflammasome were also assessed by western blot analysis and quantitative PCR. NLRP3 was silenced or overexpressed in different esophageal squamous cell carcinoma (ESCC) cell lines, and cell viability, migration and invasion were assessed by CCK-8 and Transwell assays. The present results showed that high NLRP3 expression in the tumor specimens was significantly associated with TNM stage and T category. Spearman's correlation analysis revealed a positive correlation between NLRP3 and the Ki-67 proliferation index. The mRNA and protein levels of NLRP3, apoptosis-associated speck-like protein containing a CARD (ASC), cleaved caspase-1, and interleukin (IL)-1 $\beta$ in tumor
\end{abstract}

Correspondence to: Professor Li-Rong Zhang or Dr Sheng-Na Han, Department of Pharmacology, Basic Medical School, Zhengzhou University, 100 Science Avenue, Zhengzhou, Henan 450001, P.R. China

E-mail: zhanglirongzzu@126.com

E-mail: hanshengna@126.com

Key words: NLRP3 inflammasome, esophageal squamous cell carcinoma, cell proliferation, migration, invasion, Ki-67 tissues were higher than those in non-cancerous tissues. The level of secreted IL-1 $\beta$ in tumor tissues was also increased, as compared to that in normal tissues. Silencing of NLRP3 in KYSE-70 and TE13 cells strongly attenuated cell viability, decreased cell mobility in wound-healing assays and greatly diminished the ability of cell migration and invasion in the Transwell system. Overexpression of NLRP3 in KYSE-510 and EC9706 cells markedly promoted the proliferation, migration and invasion. Collectively, these results revealed that the the NLRP3 inflammasome is upregulated in human ESCC tissues and promotes ESCC progression. Hence, NLRP3 could be a promising new candidate diagnostic and prognostic target.

\section{Introduction}

Esophageal cancer (EC) has a high incidence with marked geographical delineations (1). Esophageal squamous cell carcinoma (ESCC) is the most common pathological form of EC in China (2). In 2015, the incidence and mortality rates of EC were reported to be extremely high, accounting for $25 \%$ of the total cancer-related mortality (3). Surgery, medication and radiation therapy are the main treatment options for ESCC; however, survival rates remain poor, rendering further effort for developing new therapeutic strategies necessary $(4,5)$.

Inflammation and immunity are among the many factors that influence cancer initiation and development (6). Inflammasomes are multi-protein platforms that activate procaspase- 1 and mature interleukin (IL)-18 and IL-1 $\beta$ (7), the latter of which is associated with carcinogenesis, when its expression is increased (8). NLR pyrin family domain containing 3 (NLRP3) is an important member of the inflammasome family, which recruits apoptosis-associated speck-like protein containing a CARD (ASC) and pro-caspase-1, and further self-hydrolyzes into active caspase-1, leading to the maturation and secretion of IL-1 $\beta$ and IL-18 (9).

The NLRP3 inflammasome, which could initiate inflammatory responses, is considered to contribute to the 
development of cancer-related inflammation and play a crucial role in tumorigenesis $(10,11)$. Recent evidence has also shown that the malignant phenotype of human melanoma, as well as lung and colon carcinoma, are associated with the excessive expression and constitutive activation of the NLRP3 inflammasome (12-14). The activated NLRP3 inflammasome may suppress the antitumor effect of gemcitabine and 5-fluorouracil, thus promoting tumor growth (15). By contrast, the expression level of the NLRP3 inflammasome was found to be negatively associated with human hepatic cell carcinoma (16). Therefore, the role of the NLRP3 inflammasome in tumor initiation and promotion remains controversial and appears to be dependent on tumor type. However, there are only a few reports on the association of the NLRP3 inflammasome with EC.

Therefore, the potential effect of the NLRP3 inflammasome on human ESCC tissues and cell lines was explored, in order to identify a new clinical diagnostic and prognostic target of ESCC.

\section{Materials and methods}

Patients and tumor samples. We obtained 84 paired ESCC and adjacent non-cancerous tissues from patients who underwent surgery at the First Clinical Hospital of Zhengzhou University (Zhengzhou, Henan, China) from July 2015 to June 2017. Surgical patients had not received any prior treatment. The Ethics Committee of Zhengzhou University approved this project, and all patients signed informed consent. Out of the 84 patient samples, 42 were used as the first cohort for immunohistochemistry (IHC), which was used to evaluate the relationship between the NLRP3 inflammasome and patient clinical characteristics, and tissue microarrays. The other 42 were used as the second cohort and kept in liquid nitrogen for gene and protein expression detection.

IHC analysis. IHC was performed as previously described (17). Briefly, paraffin-embedded ESCC tissues were dewaxed, hydrated, inactivated and blocked. The tissue slides were then incubated with the primary antibodies: Rabbit polyclonal NLRP3 antibody (cat. no. ab214185; dilution 1:200; Abcam), rabbit polyclonal IL-1 beta antibody (cat. no. ab9722; dilution, 1:500; Abcam), mouse monoclonal Ki-67 antibody (cat. no. 9449S; dilution, 1:200; Cell Signaling Technology, Inc.; CST), polyclonal antibody specific for human ASC (cat. no. AL177; dilution, 1:500; AdipoGen Life Sciences, Inc.) or rabbit monoclonal caspase-1 antibody (cat. no. ab108362; dilution, 1:50; Abcam) overnight at $4^{\circ} \mathrm{C}$. They were then incubated with secondary antibodies for $1 \mathrm{~h}$ at $37^{\circ} \mathrm{C}$. The slides were photographed and mounted, and the $\mathrm{H}$-score was calculated to evaluate the expression of NLRP3, Ki-67 and IL-1 $\beta$ in a semi-quantitative manner. The $\mathrm{H}$-score was calculated, according to the staining intensity and percentage of occupancy, as the weak stain percentage multiplied by the factor 1 plus the medium stain percentage multiplied by the factor 2 plus the strong stain percentage multiplied by the factor 3 ; score range, 0-300 (18).

Hematoxylin and eosin $(H \& E)$ staining. The ESCC tissues were fixed with $10 \%$ formaldehyde and paraffin-embedded. The dried slices were dewaxed with xylene, hydrated with anhydrous ethanol, 95, 85, 75 and 50\% alcohol and distilled water step by step, and then stained with H\&E. Pathological changes in the tissues were observed under a field of x100 and x400 magnification under optical microscopy.

RNA extraction and reverse transcription-quantitative polymerase chain reaction ( $R T-q P C R)$. Total RNA from ESCC tissues was isolated using Trizol (cat. no. 15596026; Thermo Fisher Scientific, Inc.), and quantified on a NanoDrop 2000 spectrometer (Thermo Fisher Scientific, Inc.). The cDNA was reverse-transcribed from $1 \mu \mathrm{g}$ of total RNA using the Prime Script RT reagent kit (cat. no. 4472908; Takara Bio), and then used as a template for RT-qPCR in the SYBR-Green Master Mix kit (cat. no. A25779; Thermo Fisher Scientific, Inc.). The thermal cycling conditions used were as follows: Holding at $50^{\circ} \mathrm{C}$ for $2 \mathrm{~min}$, pre-denaturation at $95^{\circ} \mathrm{C}$ for $2 \mathrm{~min}, 40$ cycles of $95^{\circ} \mathrm{C}$ for $15 \mathrm{sec}$ and $60^{\circ} \mathrm{C}$ for $1 \mathrm{~min}$. The $2^{-\Delta \Delta \mathrm{CT}}$ method was used to assess RNA levels normalized to the $\beta$-actin level (19). The primer sequences were designed and are listed in Table I.

Western blot analysis. Tissues or cell proteins were extracted using RIPA lysis buffer (Beijing Solarbio Science \& Technology Co., Ltd.) with a protease inhibitor cocktail (Beyotime Institute of Biotechnology). First, equal amounts of proteins $(50 \mu \mathrm{g})$ were subjected to $10 \%$ sodium dodecyl sulfate-polyacrylamide gel (SDS-PAGE) electrophoresis and then transferred onto polyvinylidene fluoride membranes. Next, $5 \%$ fat-free milk was used to block the membranes for $2 \mathrm{~h}$, which were then incubated with primary antibodies: Rabbit polyclonal NLRP3 antibody (cat. no. ab214185; dilution, 1:2,000; Abcam), rabbit monoclonal caspase-1 antibody (cat. no. ab108362; 1:1,000; Abcam), rabbit polyclonal IL-1 $\beta$ antibody (cat. no. ab9722; dilution, 1:1,000; Abcam), polyclonal antibody specific for human ASC (cat.no. AL177; dilution, 1:1,000; AdipoGen Life Sciences, Inc.), and mouse monoclonal $\beta$-actin antibody (cat. no. 60008-1; dilution, 1:5,000; ProteinTech Group, Inc.) overnight at $4^{\circ} \mathrm{C}$. Then the blots were incubated with secondary antibodies, including HRP-conjugated AffiniPure goat anti-rabbit IgG $(\mathrm{H}+\mathrm{L})$ (cat. no. SA00001-2; dilution, 1:5,000; ProteinTech Group, Inc.) and HRP-conjugated AffiniPure goat anti-mouse $\operatorname{IgG}(\mathrm{H}+\mathrm{L})$ (cat. no. SA00001-1; dilution, 1:5,000; ProteinTech Group, Inc.) at $37^{\circ} \mathrm{C}$. After $2 \mathrm{~h}$, immunoreactive bands were visualized using an ECL system ((FluorChem E; ProteinSimple).

Enzyme-linked immunosorbent assay (ELISA). To assess the content of tissue-derived IL-1 $\beta$ in ESCC, frozen tissue samples were thawed and weighed, and $100 \mathrm{mg}$ per tissue was transferred into tubes on ice containing $900 \mathrm{ml}$ PBS. The samples were homogenized and then centrifuged at $5,000 \mathrm{x}$ g at $4^{\circ} \mathrm{C}$ for $10 \mathrm{~min}$. A BCA kit (Beyotime Institute of Biotechnology) was used to determine the total protein concentration in the supernatant. A commercial ELISA kit (BioLegend) was used to measure the levels of IL-1 $\beta$, expressed as $\mathrm{pg} / \mathrm{ml}$.

Cell lines. The human KYSE-70, EC109, KYSE-510, TE1, TE13, EC1 and EC9706 ESCC cell lines and the normal esophageal squamous epithelium HET-1A cell line were provided by Basic Medical Sciences of Zhengzhou University (Zhengzhou, China). TE13 cell authentication has been identified by 
Table I. Primer sequences for RT-qPCR.

\begin{tabular}{lll}
\hline Gene & \multicolumn{1}{c}{ Forward (5'-3') } & \multicolumn{1}{c}{ Reverse $\left(5^{\prime}-3^{\prime}\right)$} \\
\hline$\beta$ - actin & GGGAAATCGTGCGTGACATT & GGAAGGAAGGCTGGAAGAGT \\
ASC $\mathrm{A} C$ & GCTGCGATCAACAGGAGAGA & GCTCACACTCTCACCCAGA \\
Caspase- 1 & AAGCCAGGCCTGCACTTTAT & AGAGCTTCCGCATCTTGCTT \\
$I L-1 \beta$ & CATCCCACAATGGGCTCTGT & TCACTCTTTCAGTGGTGGGC \\
& TGAGCTCGCCAGTGAAATGA & TGAGCTCGCCAGTGAAATGA
\end{tabular}

$N L R P 3$, NLR pyrin family domain containing 3; ASC, apoptosis-associated speck-like protein containing a CARD; $I L-1 \beta$, interleukin-1 $\beta$.

STR profiling. Cells were incubated in RPMI-1640 medium (Gibco; Thermo Fisher Scientific, Inc.), containing 10\% FBS (Corning Inc.) and $1 \%$ penicillin and streptomycin with $5 \% \mathrm{CO}_{2}$ at $37^{\circ} \mathrm{C}$.

Cell transfection. To knockdown NLRP3, KYSE-70 and TE13 cells were transfected with NLRP3-small interfering RNA (siRNA) and a non-silencing siRNA (Guangzhou RiboBio Co., Ltd.), as negative control. For RNA interference, 50 pmol siRNA was transiently transfected into the cells using $3.75 \mu \mathrm{l}$ Lipofectamine ${ }^{\mathrm{TM}} 3000$ Reagent (Thermo Fisher Scientific, Inc.) and then cells were incubated for $48 \mathrm{~h}$.

To overexpress NLRP3, KYSE-510 and EC9706 cells were transfected with the plasmid pCDNA3.1 (+)-NLRP3 and pcDNA-3.1(+) vector plasmid as negative control. Cells were then incubated for $18 \mathrm{~h}$, and then transfection was conducted with Lipofectamine ${ }^{\mathrm{TM}} 3000$ Reagent and $\mathrm{P} 3000^{\mathrm{TM}}$ reagent (Thermo Fisher Scientific, Inc.) following the manufacturer's instructions.

Cell proliferation assay. In 96 -well plates, $5 \times 10^{3}$ cells per well were cultured for $6,12,24$ and $48 \mathrm{~h}$. At each time point, $10 \mu \mathrm{l}$ CCK-8 chemical compound was added to the cell supernatant. After $2 \mathrm{~h}$, cell absorbance was determined at $450 \mathrm{~nm}$ using a spectrophotometer (Thermo Fisher Scientific, Inc.).

Wound healing assay. For the wound healing assay, $1 \times 10^{5}$ cells per well were inoculated in 6-well plates. Cells were allowed to grow until $90 \%$ confluency, then a gap was made using a 200- $\mu$ l pipette tip. Then, the cells were cultured with fresh RPMI-1640 medium contained 1\% FBS. The distance of wound closure was measured at $0,6,12,24$ and $48 \mathrm{~h}$, respectively. The percent wound closure was determined using the following equation: $\left(A_{0}-A_{t}\right) / A_{0} \times 100$, where $A_{0}$ is the wound area at the hour of the wound generation, and $A_{t}$ is the wound area at the hour of observation.

Cell migration and invasion assays. Transwell assay was used to detect the ability of cell migration and invasion, as previously described (20). Briefly, $1 \times 10^{4}$ cells were inoculated in an inner Transwell chamber ( $8 \mu \mathrm{m}$; Corning Inc.), which was pre-coated with or without $300 \mu \mathrm{g} / \mathrm{ml}$ Matrigel (BD Biosciences) for $2 \mathrm{~h}$. The outer chamber was filled with $20 \%$ FBS in RPMI-1640 medium as an inducer. After $48 \mathrm{~h}$, the migrated cells were fixed, stained with $0.1 \%$ crystal violet and counted (magnification, $\mathrm{x} 200$ ) in five different areas under an inverted fluorescence microscope (Nikon Eclipse TS100-F; Nikon).

Statistical analysis. SPSS software version 3 (SPSS, Inc.) and GraphPad Prism 5 (GraphPad software, Inc.) were used for statistical analysis and plotting, respectively. One-way analysis of variance (ANOVA) followed by Tukey's post hoc test was used to analyze the difference for more than two groups. The two-tailed Student's t-test was used for comparison of two groups. Repeated measurement ANOVA was used to analyze cell viability and wound closure at different time intervals for each group, separately. Comparison of NLRP3 or IL-1 $\beta$ and patient clinical characteristics was performed using $\chi^{2}$ or Fisher's exact test. The Spearman's correlation analysis was used for the correlation between Ki-67 and NLRP3. In this study, $\mathrm{P}<0.05$ was considered statistically significant. Data are presented as the mean \pm SD. The data are derived from cell experiments with 3 independently repeats.

\section{Results}

Increased levels of the NLRP3 inflammasome in human ESCC tissues. IHC of the first cohort containing 42 ESCC and matched adjacent non-cancerous tissue samples showed that NLRP3 and the three other main inflammasome components, ASC, caspase-1 and IL-1 $\beta$, were weakly expressed in adjacent control tissues but highly expressed in the tumor tissues (Fig. 1A-D). We demonstrated that the H-scores of immunostaining positive NLRP3, ASC, caspase-1 and IL-1 $\beta$ in tumor tissues were significantly higher than these scores in the adjacent control tissues (Fig. 1E-H).

Next, the mRNA and protein levels of NLRP3, ASC, IL-1 $\beta$ and caspase- 1 in the second cohort of 42 fresh ESCC samples were assessed by RT-qPCR and western blot analysis. The mRNA levels of NLRP3 (18/42, 42.86\%; $\mathrm{P}=0.009), A S C$ $(23 / 42,54.76 \% ; \mathrm{P}=0.008)$, caspase-1 $(21 / 42,50.00 \%$; $\mathrm{P}=0.003)$ and $I L-1 \beta(27 / 42,64.28 \%, \mathrm{P}=0.001)$ were increased more than two-fold in the tumors (Fig. 2A). Western blot analysis confirmed higher expression levels of NLRP3, ASC, caspase-1 and IL-1 $\beta$ in the tumors (Fig. $2 \mathrm{~B}$ ). Additionally, IL- $1 \beta$ secreted in the tumors was higher than that in adjacent non-cancerous tissues ( $n=32, P=0.001$; Fig. $2 \mathrm{C}$ and D).

Association of the NLRP3 or IL-1 $\beta$ expression and clinical characteristics. A higher NLRP3 protein expression was detected in 22 tumor samples $(52.38 \%)$ of the first cohort, as 

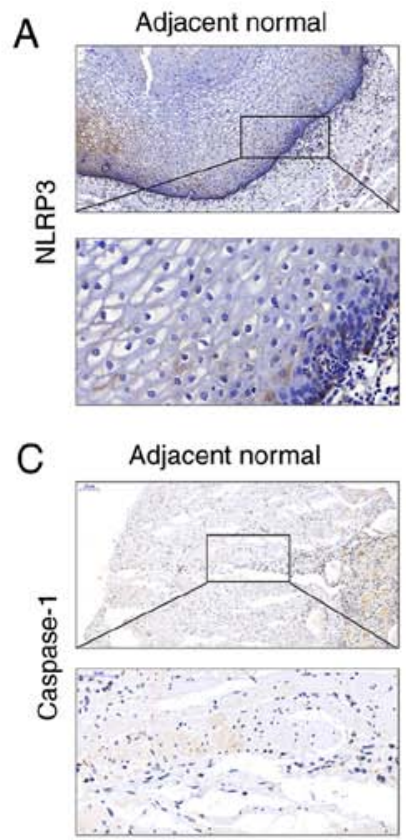

E

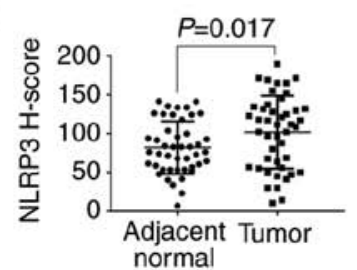

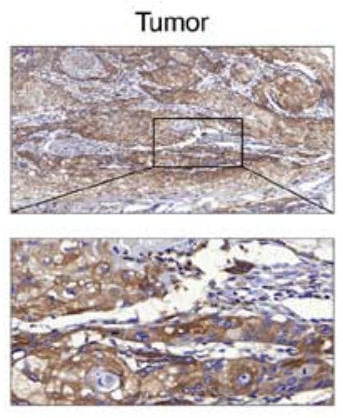

Tumor
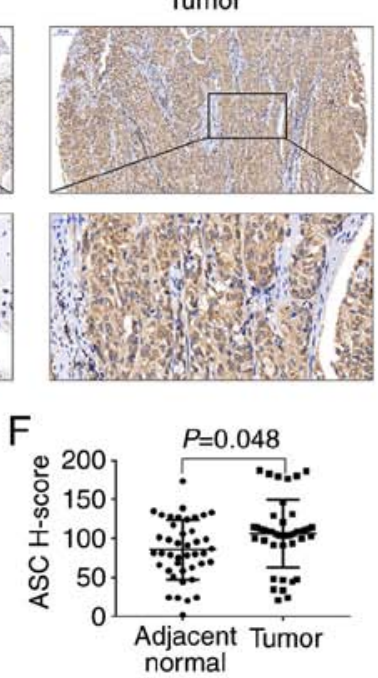

B
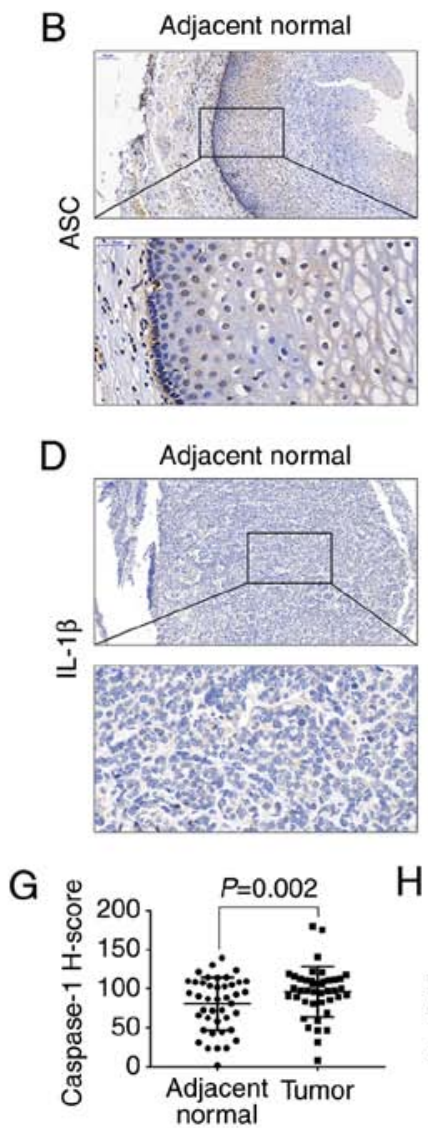
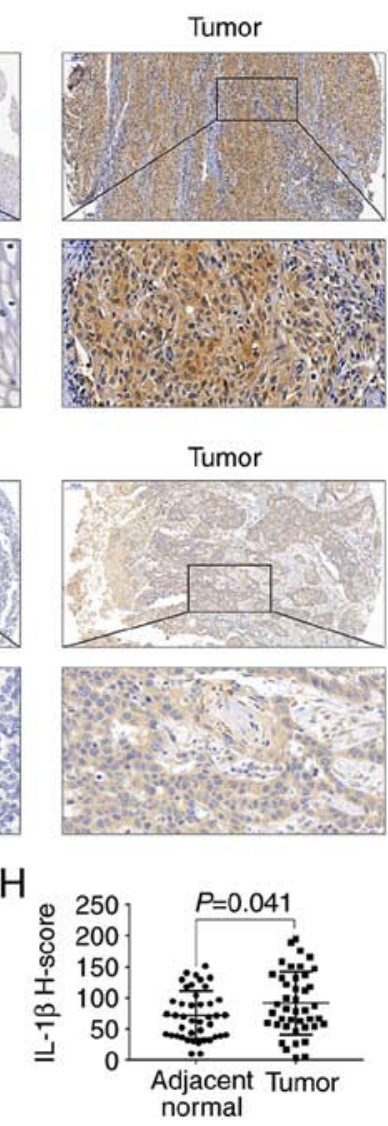

Figure 1. Expression levels of (A) NLRP3, (B) ASC, (C) caspase-1 and (D) IL-1 $\beta$ proteins were elevated in tumor tissues from the first cohort (n=42). The inflammasome had a relatively stronger staining in the tumor tissue than that noted in the adjacent normal tissues. The immunostaining positive $\mathrm{H}$-scored for $(\mathrm{E}) \mathrm{NLRP} 3(\mathrm{P}=0.017),(\mathrm{F})$ ASC $(\mathrm{P}=0.048),(\mathrm{G})$ caspase-1 $(\mathrm{P}=0.002)$ and $(\mathrm{H}) \mathrm{IL}-1 \beta(\mathrm{P}=0.041)$ in tumor tissues were significantly higher than these scores in the adjacent tissues. Magnification, x100 for upper panel images; x400 for lower panel images. NLRP3, NLR pyrin family domain containing 3; ASC, apoptosis-associated speck-like protein containing a CARD; IL, interleukin.

compared with the control tissues. An increased NLRP3 protein expression was found to be associated with the T category and TNM stage $(\mathrm{P}=0.032$ and $\mathrm{P}=0.021$, respectively), but not with the age, sex, lymph node status and metastasis status of the patients (Table II). The NLRP3 protein expression was higher in pathologic stage III-IV than I-II. Similarly, a higher IL-1 $\beta$ protein expression was found to be significantly associated with $\mathrm{T}$ category $(\mathrm{P}=0.014)$ and lymph node status $(\mathrm{P}=0.005$; Table II), as determined by IHC. A high protein expression level of NLRP3 was found to be associated with T category and TNM stage $(\mathrm{P}=0.030$ and $\mathrm{P}=0.020$, respectively) in the second cohort (Table III), as determined by western blot analysis.

Association between NLRP3 and Ki-67 expression. The expression of the proliferation marker Ki-67 was explored and its association with NLRP3 was evaluated. The paraffin sections of the first cohort of 42 ESCC samples were IHC-stained for Ki-67 expression. The IHC results revealed that the Ki-67 expression was higher in the tumor tissues than that in the adjacent non-cancerous tissues (Fig. 3A). H-score of Ki-67 immunostaining-positive cells was significantly higher in cancer tissues than that in the normal tissues (Fig. 3B). Organic tissues were confirmed by pathological diagnosis following H\&E staining, and the results revealed a complete structure and orderly arrangement of cells in normal tissues, but in cancer tissues obvious atypia, diffuse distribution, vigorous growth, irregular arrangement, large nuclei and dark cytoplasm (Fig. 3C). Patients were divided into a low and high Ki-67 group, according to the relative expression of $\mathrm{Ki}-67$ in cancer tissues, as compared to normal tissues. A positive correlation between Ki-67 and NLRP3 was revealed by Spearman's correlation analysis $(\mathrm{P}=0.014, \mathrm{r}=0.355$; Table IV). These data indicated that Ki-67-positive patients tend to have a higher NLRP3 expression.

NLRP3 silencing reduces cell proliferation, migration and invasion. Seven ESCC cell lines were selected for western blot analysis to study the expression of NLRP3. The results showed that TE13 and KYSE-70 cells had the highest expression levels of NLRP3, whereas EC9706 and KYSE-510 cells had the lowest (Fig. 4A).

Next, TE13 and KYSE-70 cells were transfected with NLRP3-siRNAs (siRNA-NLRP3-1 and siRNA-NLRP3-2), respectively, and siRNA knockdown efficacy was confirmed by RT-qPCR and western blot analysis; siRNA-NLRP3-2 was selected for further experiments, due to its more effective inhibition of NLRP3 in the TE13 ( $\mathrm{P}=0.037)$ and KYSE-70 cell lines $(\mathrm{P}=0.003)$ (Fig. 4B and C). Silencing of NLRP3 strongly attenuated the cell viability of TE13 $(\mathrm{P}=0.01)$ and KYSE-70 $(\mathrm{P}=0.0004)$ cells, respectively (Fig. 4F and $\mathrm{G})$, decreased cell 
A
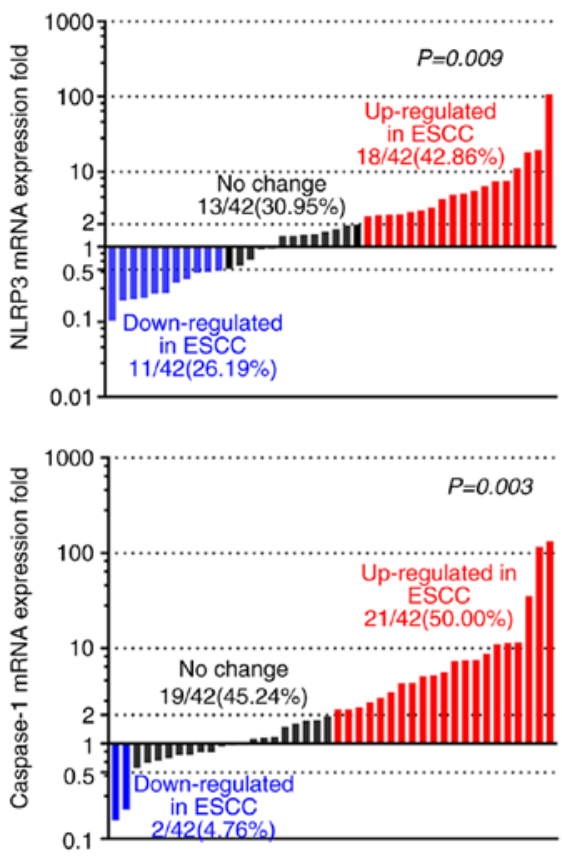
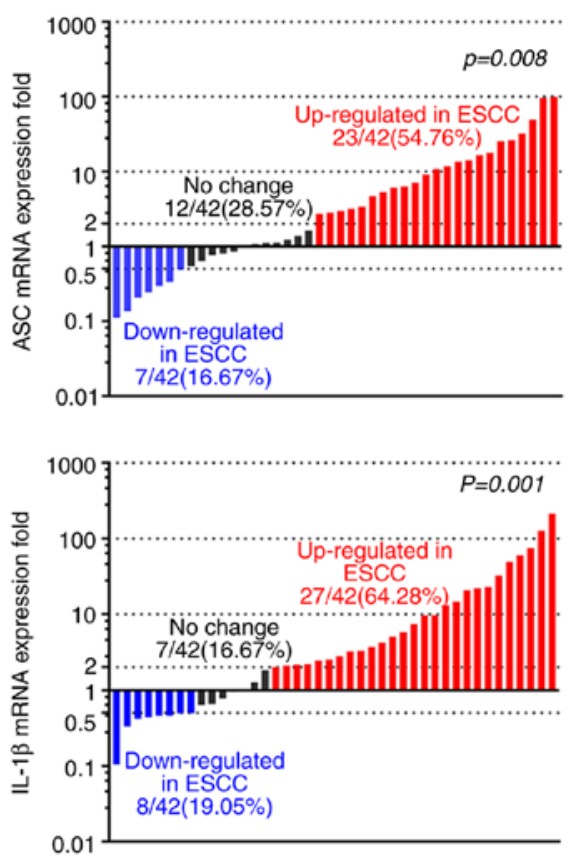

B
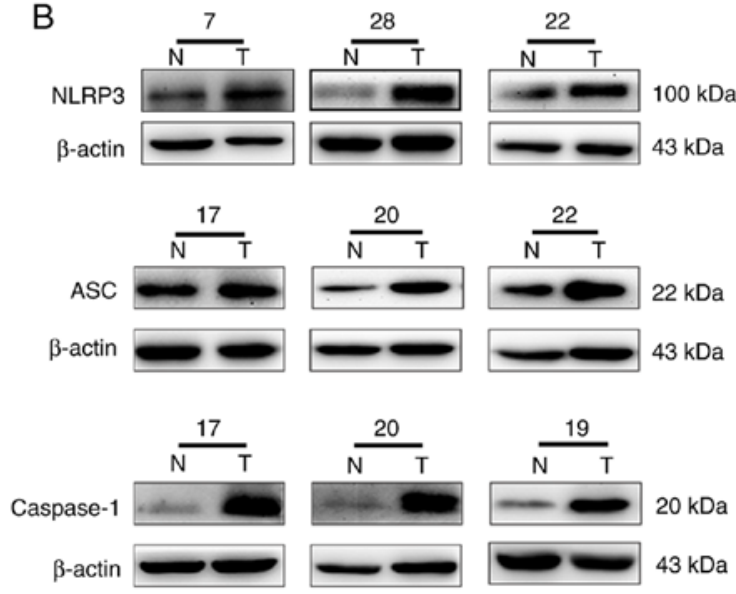

$20 \mathrm{kDa}$
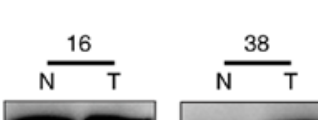

IL-1及

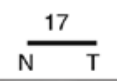

$\beta$-actin
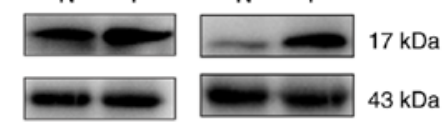

C

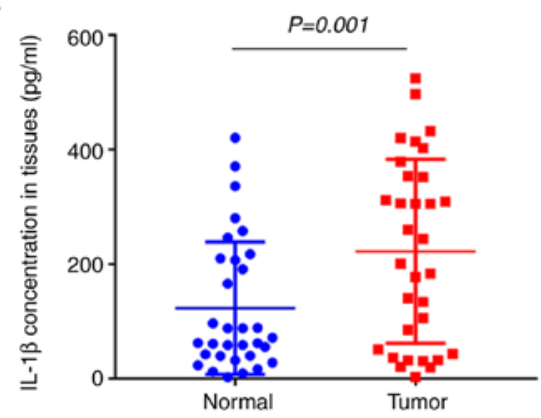

D

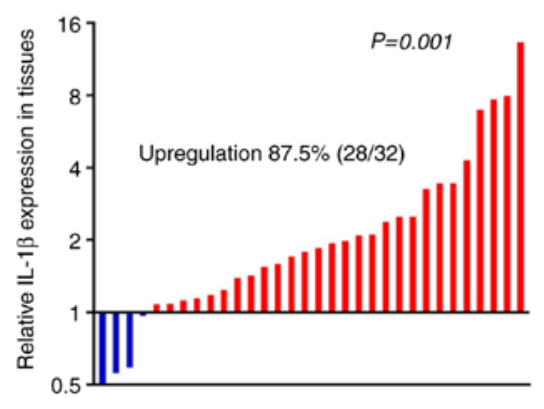

Figure 2. Expression levels of NLRP3 and main inflammasome components are increased in ESCC tissues from the second cohort. (A) mRNA expression levels of NLRP3 ( $\mathrm{P}=0.009)$, ASC $(\mathrm{P}=0.008)$, caspase-1 $(\mathrm{P}=0.003)$ and IL-1 $\beta(\mathrm{P}=0.001)$ in ESCC and adjacent normal tissues were determined by RT-qPCR $(\mathrm{n}=42)$. These bars represent the fold change of mRNA expression of ESCC compared with adjacent noncancerous tissues. Red bars, $\geq 2$-fold increase; blue bars, $\geq 2$-fold decrease; black bars, fold change of mRNA are $<2$-fold. (B) The protein expression levels of NLRP3, ASC, caspase-1 and IL-1 $\beta$ in ESCC tissues (T) and adjacent normal tissues $(\mathrm{N})$ were determined by western blot analysis $(\mathrm{n}=42)$. The number above each western blot is the patient number. $(C$ and $D)$ IL-1 $\beta$ expression in the tissues was detected by ELISA $(n=32, P=0.001)$. NLRP3, NLR pyrin family domain containing 3; ESCC, esophageal squamous cell carcinoma; ASC, apoptosis-associated speck-like protein containing a CARD; IL, interleukin; RT-qPCR, reverse transcription-quantitative polymerase chain reaction; ELISA, enzyme-linked immunosorbent assay. 


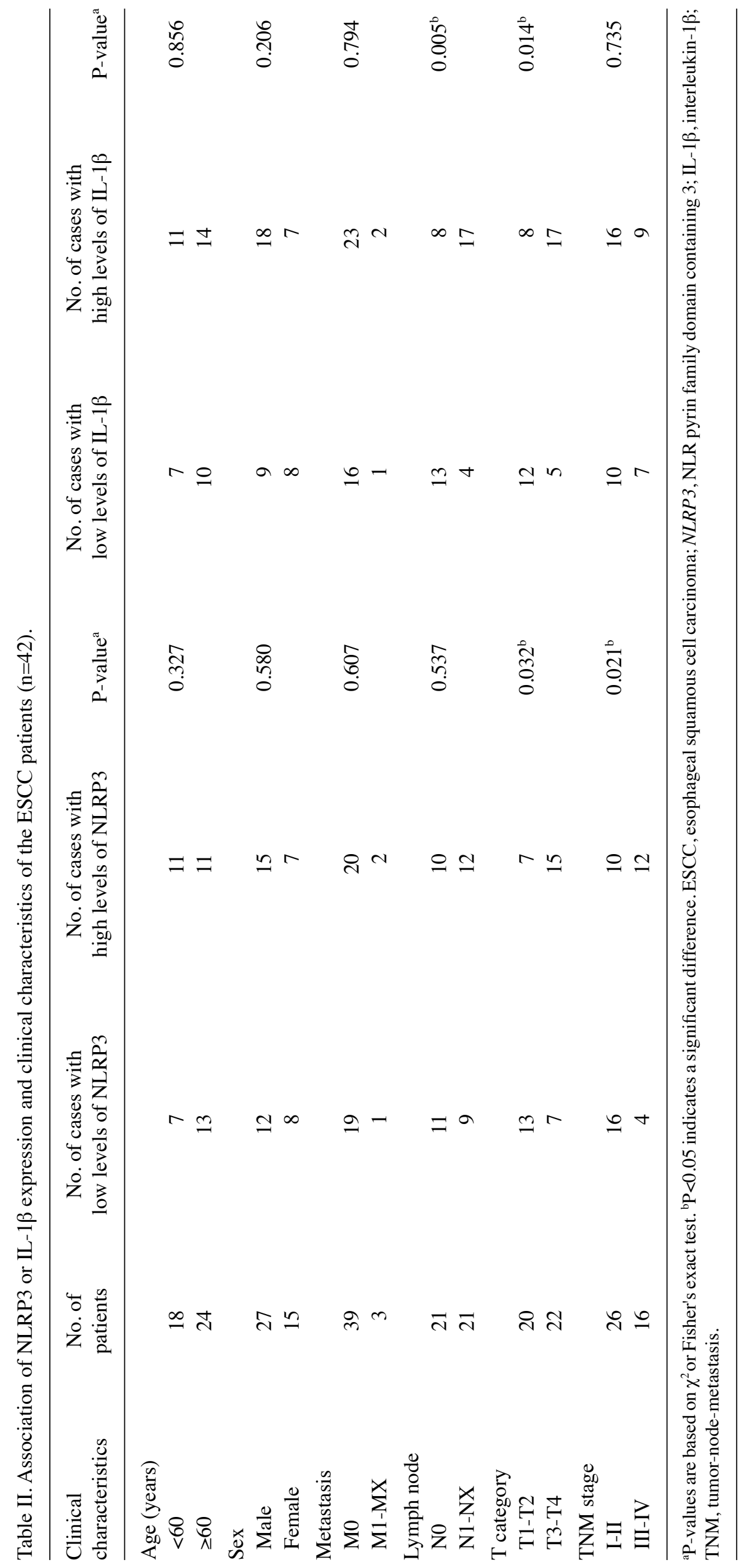


Table III. Comparison of NLRP3 expression and the clinical characteristics of the ESCC patients $(\mathrm{n}=42)$.

\begin{tabular}{|c|c|c|c|c|}
\hline $\begin{array}{l}\text { Clinical } \\
\text { characteristics }\end{array}$ & $\begin{array}{l}\text { No. of } \\
\text { patients }\end{array}$ & $\begin{array}{l}\text { No. of cases with } \\
\text { low levels of NLRP3 }\end{array}$ & $\begin{array}{c}\text { No. of cases with } \\
\text { high levels of NLRP3 }\end{array}$ & P-value ${ }^{a}$ \\
\hline \multicolumn{5}{|l|}{ Age (years) } \\
\hline$<60$ & 14 & 5 & 9 & \multirow[t]{2}{*}{0.381} \\
\hline$\geq 60$ & 28 & 14 & 14 & \\
\hline \multicolumn{5}{|l|}{ Sex } \\
\hline Male & 27 & 13 & 14 & \multirow[t]{2}{*}{0.611} \\
\hline Female & 15 & 6 & 9 & \\
\hline \multicolumn{5}{|l|}{ Metastasis } \\
\hline M0 & 42 & 19 & 23 & \\
\hline M1-MX & 0 & 0 & 0 & \\
\hline \multicolumn{5}{|l|}{ Lymph node } \\
\hline No & 20 & 11 & 9 & \multirow[t]{2}{*}{0.226} \\
\hline N1-NX & 22 & 8 & 14 & \\
\hline \multicolumn{5}{|l|}{$\mathrm{T}$ category } \\
\hline $\mathrm{T} 1-\mathrm{T} 2$ & 21 & 13 & 8 & \multirow[t]{2}{*}{$0.030^{\mathrm{b}}$} \\
\hline T3-T4 & 21 & 6 & 15 & \\
\hline \multicolumn{5}{|l|}{ TNM stage } \\
\hline I-II & 25 & 15 & 10 & \multirow[t]{2}{*}{$0.020^{\mathrm{b}}$} \\
\hline III-IV & 17 & 4 & 13 & \\
\hline
\end{tabular}

${ }^{a} \mathrm{P}$-values are based on $\chi^{2}$ or Fisher's exact test. ${ }^{b} \mathrm{P}<0.05$ indicates significance. ESCC, esophageal squamous cell carcinoma; NLRP3, NLR pyrin family domain containing 3; TNM, tumor-node-metastasis.
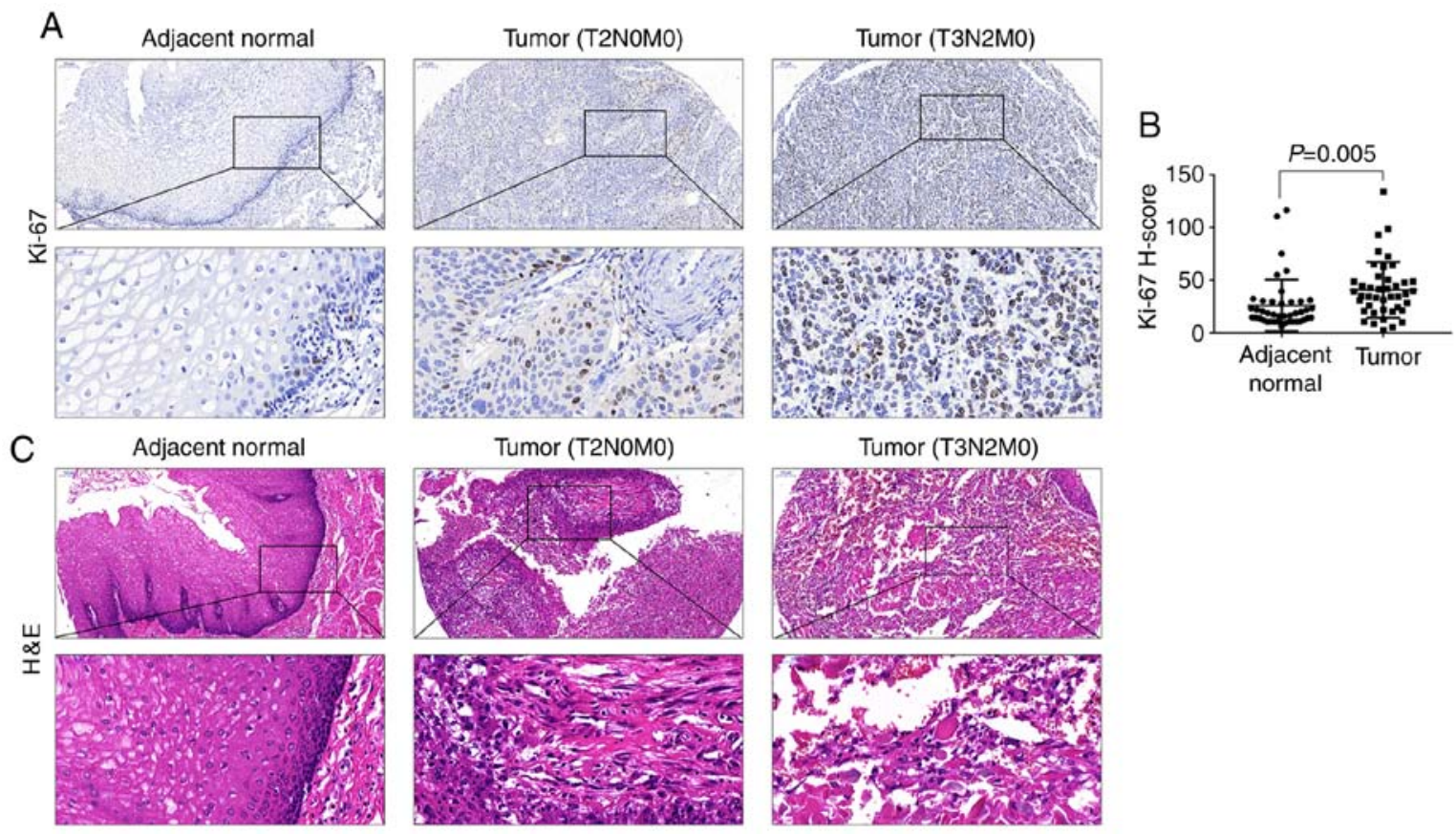

Figure 3. Ki-67 expression is higher in the tumor than that in the adjacent non-cancerous tissues. (A) Representative images of IHC staining for Ki-67. (B) The $\mathrm{H}$-score for Ki-67 in cancer tissues was significantly higher than that in the normal tissues ( $\mathrm{P}=0.005)$. (C) H\&E staining in the tissues of patients with ESCC $(\mathrm{n}=42)$. Magnification, $\mathrm{x} 100$ for upper images; magnification of squared areas, $\mathrm{x} 400$ in the lower pane. IHC, immunohistochemical; H\&E, hematoxylin and eosin; ESCC, esophageal squamous cell carcinoma.

mobility in the wound-healing assays in the TE13 $(\mathrm{P}=0.015$, Fig. 5A and C) and KYSE-70 (P=0.002, Fig. 5B and D) cell lines. Moreover, silencing of NLRP3 significantly decreased tumor cell invasion in the TE13 cells $(\mathrm{P}<0.0001)$ and KYSE-70 


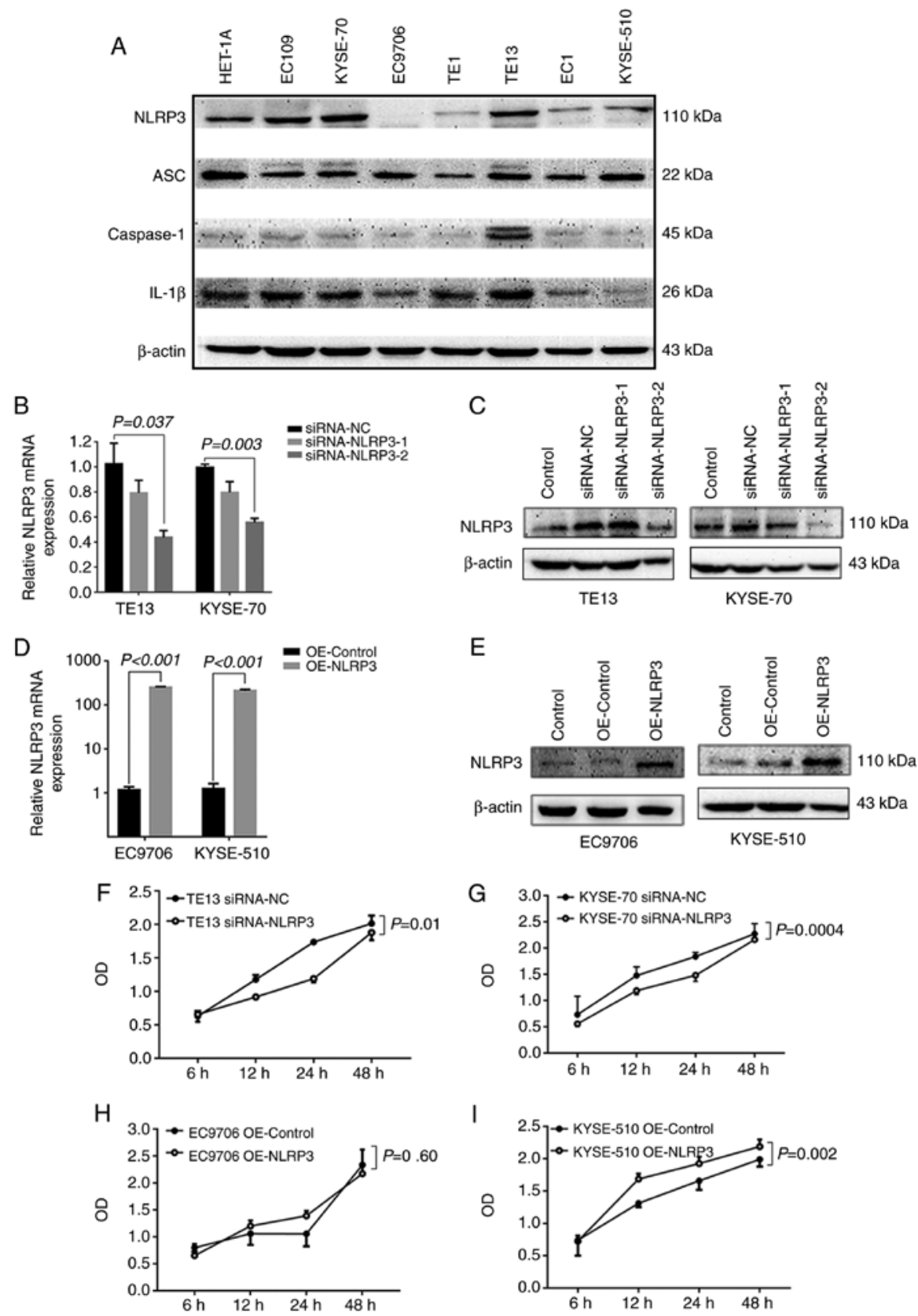

Figure 4. NLRP3 inflammasome is required for the proliferation and growth of ESCC cells ( $n=3$ ). (A) Expression levels of NLRP3, ASC, caspase-1 and IL-1 $\beta$ in 7 different ESCC cell lines as determined by western blot analysis. NLRP3 silencing (siRNA-NLRP3-1 and siRNA-NLRP3-2) decreased the (B) mRNA and (C) protein expression in TE13 $(\mathrm{P}=0.037)$ and KYSE-70 $(\mathrm{P}=0.003)$ cells. Overexpression of NLRP3 increased the $(\mathrm{D}) \mathrm{mRNA}(\mathrm{P}<0.001)$ and $(\mathrm{E})$ protein expression in EC9706 and KYSE-510 cells. (F and G) NLRP3 silencing significantly decreased the proliferation of TE13 ( $\mathrm{P}=0.01)$ and KYSE-70 cells $(\mathrm{P}=0.0004)$, as determined by the CCK-8 assay. (H and I) NLRP3 overexpression increased the proliferation of KYSE-510 cells ( $\mathrm{P}=0.002)$ and caused no significant viability increase in EC9706 ( $\mathrm{P}=0.60)$ cells. NLRP3, NLR pyrin family domain containing 3; ESCC, esophageal squamous cell carcinoma; ASC, apoptosis-associated speck-like protein containing a CARD; IL, interleukin.

Table IV. Correlation between NLRP3 and Ki-67 expression ( $\mathrm{n}=42)$.

\begin{tabular}{lrrrr}
\hline & \multicolumn{2}{c}{ Ki-67 expression } & & \\
\cline { 2 - 3 } & Low & High & P-value & $\mathrm{r}$ \\
\hline NLRP3 expression & & & & \\
Low & 12 & 8 & $0.014^{\mathrm{b}}$ & 0.355 \\
High & 5 & 17 & &
\end{tabular}

${ }^{\text {aP }}$-values are based on Spearman's correlation coefficient test. ${ }^{\text {b }}<0.05$ indicates a significant association among the variables. NLRP3, NLR pyrin family domain containing 3 .
$(\mathrm{P}=0.0002)$ cells, as well as migration in the TE13 $(\mathrm{P}<0.0001)$ and KYSE-70 ( $\mathrm{P}=0.0037)$ cells (Fig. 5E-H).

Overexpression of NLRP3 promotes ESCC biological function. pcDNA-3.1(+)-NLRP3 plasmid (OE-NLRP3) or the vector pcDNA-3.1(+) (OE-Control) was transfected into EC9706 and KYSE-510 cells with low NLRP3 expression levels $(\mathrm{P}<0.001$; Fig. 4D and E). As compared with the pcDNA-3.1(+) plasmid-transfected cells, the CCK-8 assay results showed that pcDNA-3.1(+)-NLRP3-transfected (OE-NLRP3) KYSE-510 cells had an increased viability $(\mathrm{P}=0.002)$, however, EC9706 cells showed no significant increase in viability $(\mathrm{P}=0.60)$ 
A

TE13

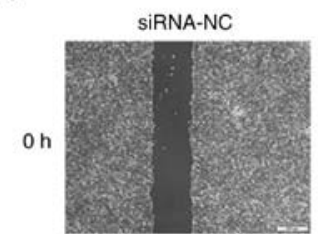

$6 \mathrm{~h}$

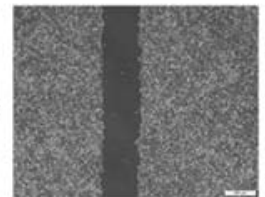

$12 \mathrm{~h}$

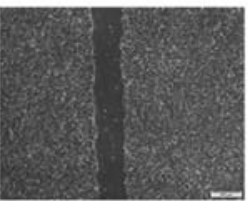

$4 \mathrm{~h}$

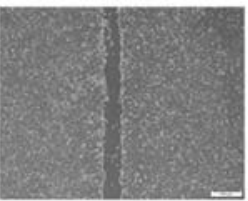

$48 \mathrm{~h}$

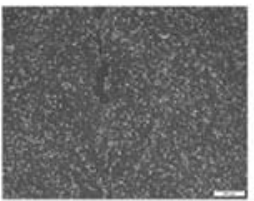

C $\quad 1007$ TE13-NC

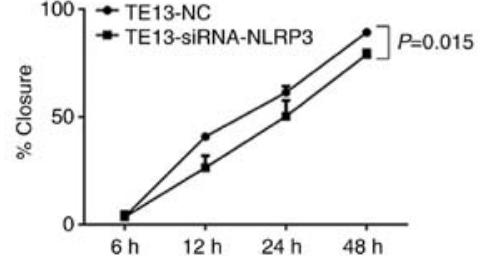

E

TE13
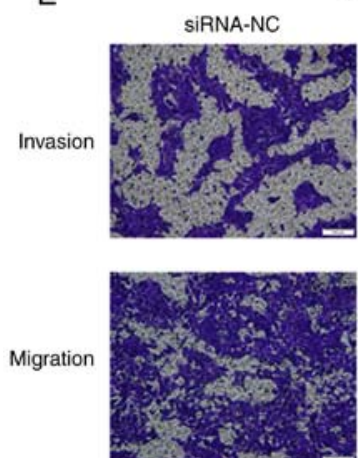

G

- TE13-siRNA-NC

- TE13-SIRNA-NLRP3
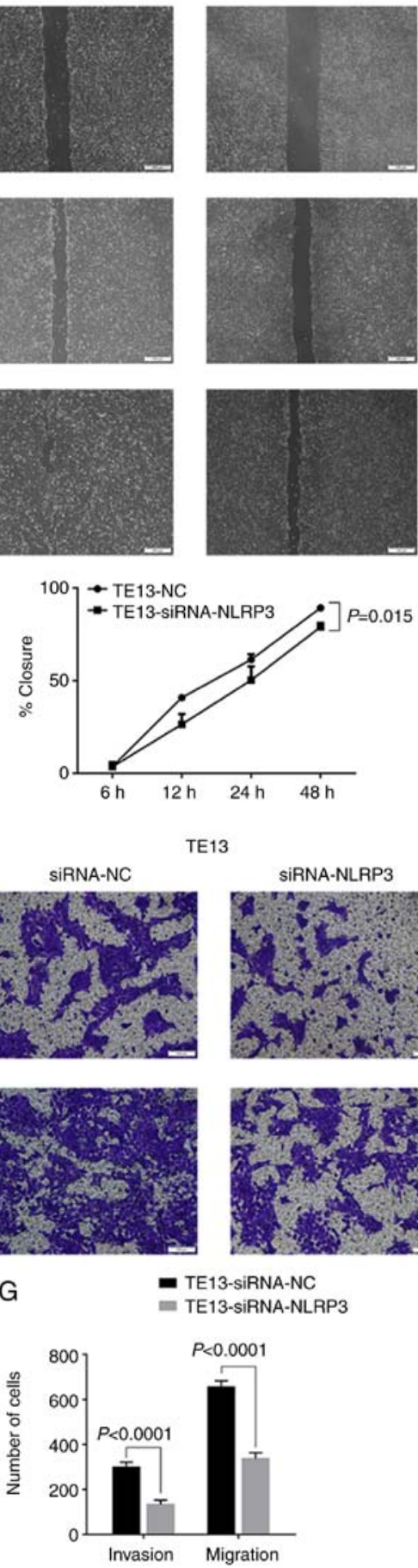

SIRNA-NLRP3
B
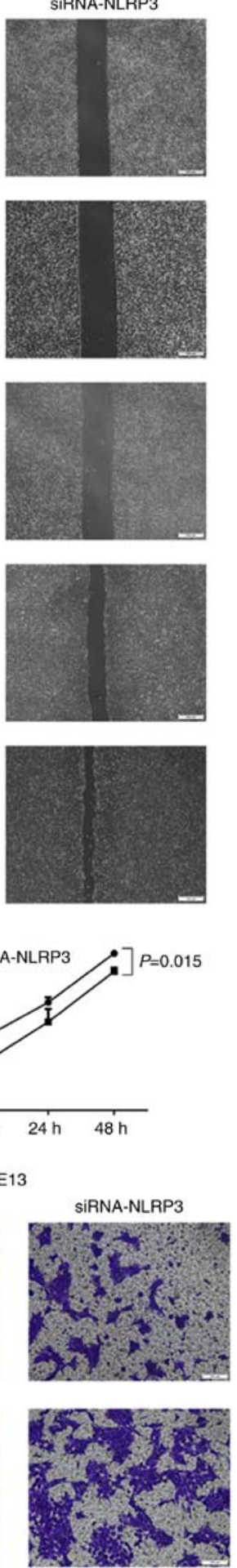

F
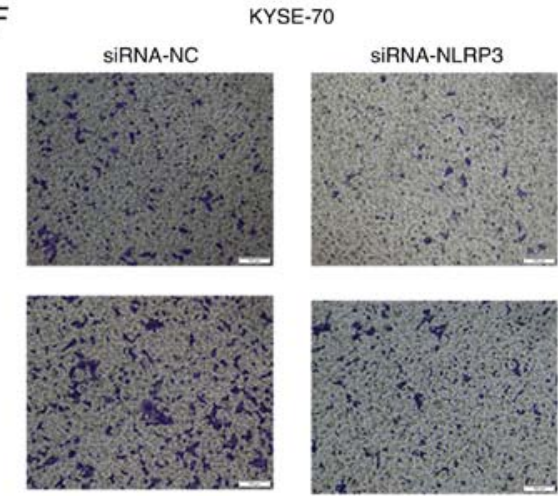

$\mathrm{H}$

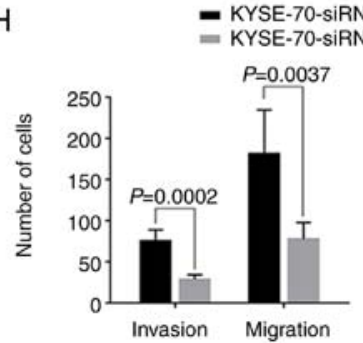

Figure 5. NLRP3 silencing reduces the invasion and migration of ESCC cells (n=3). (A-D) Wound healing assays in TE13 (P=0.015) and KYSE-70 cells $(\mathrm{P}=0.002)$ (magnification, $\mathrm{x} 100$; scale bar, $200 \mu \mathrm{m})$. $(\mathrm{E}-\mathrm{H}) \mathrm{NLRP} 3$ silencing decreased tumor cell invasion in TE13 cells $(\mathrm{P}<0.0001)$ and $\mathrm{KYSE}-70(\mathrm{P}=0.0002)$ cells and migration in TE13 ( $\mathrm{P}<0.0001)$ and KYSE-70 ( $\mathrm{P}=0.0037)$ cells (magnification, $\mathrm{x} 200$; scale bar, 100 $\mu \mathrm{m})$. NLRP3, NLR pyrin family domain containing 3; ESCC, esophageal squamous cell carcinoma. 
A
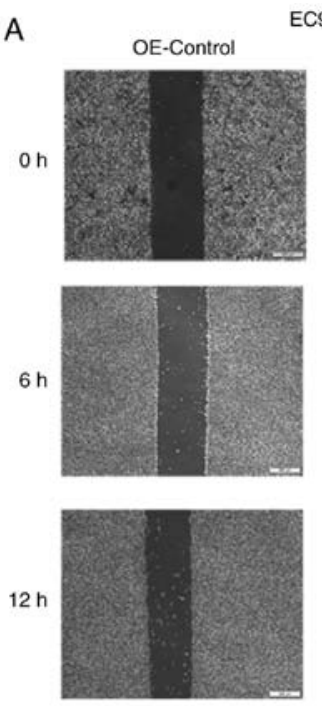

$24 \mathrm{~h}$

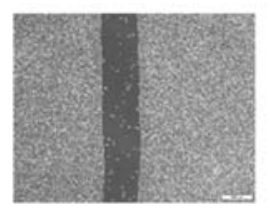

$48 \mathrm{~h}$
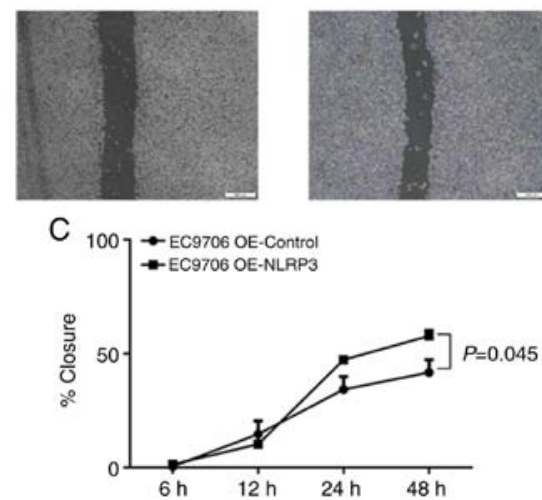

$\mathrm{E}$

EC9706

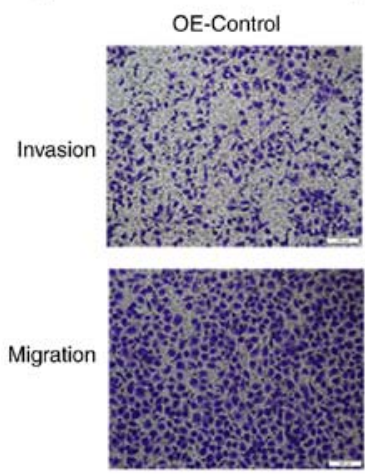

G

- EC9706-OE-Control

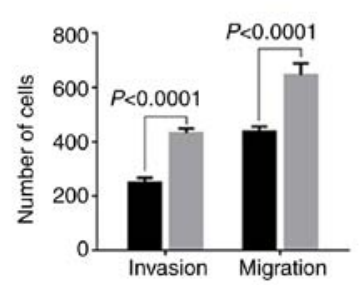

OE-NLRP3
B
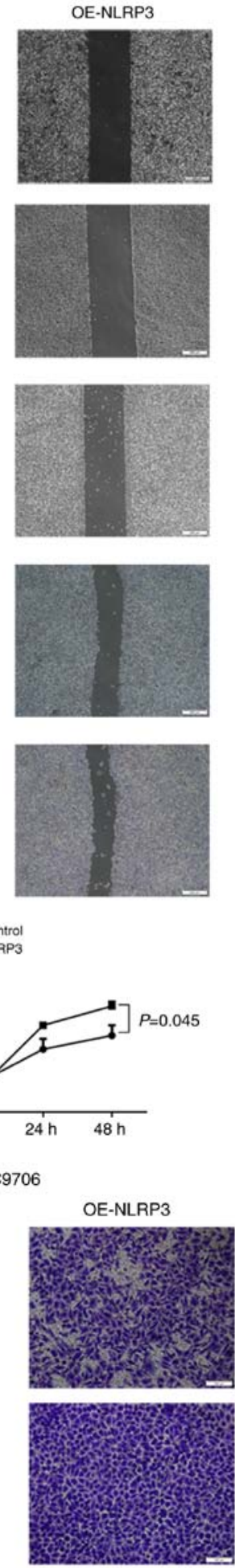

F
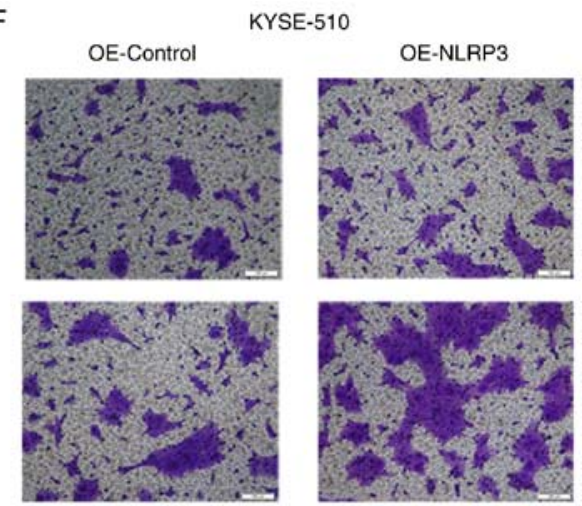

$\mathrm{H}$

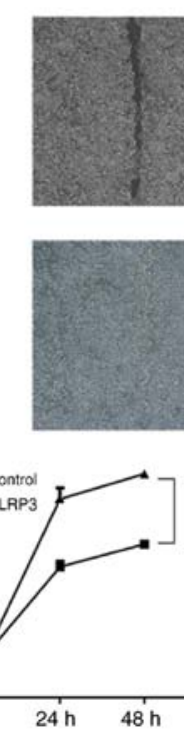

- KYSE-510-OE-Control

= KYSE-510-OE-NLRP3

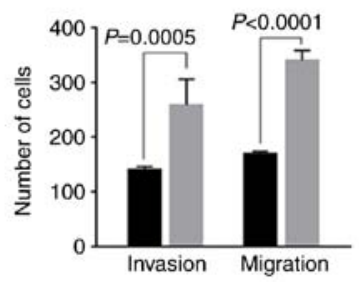

Figure 6. Overexpression of NLRP3 promotes the invasion and migration of ESCC cells ( $n=3)$. (A-D) Wound healing assays in $E C 9706$ ( $P=0.045)$ and KYSE-510 cells $(\mathrm{P}=0.021)$ (magnification, $x 100$; scale bar, $200 \mu \mathrm{m})$. ( $\mathrm{E}-\mathrm{H})$ NLRP3 upregulation increased the number of invasive cells in $\mathrm{EC} 9706(\mathrm{P}<0.0001)$ and KYSE-510 cells $(\mathrm{P}=0.0005)$ and enhanced tumor cell migration in EC9706 ( $\mathrm{P}<0.0001)$ and KYSE-510 cells $(\mathrm{P}<0.0001)($ magnification, x200; scale bar, $100 \mu \mathrm{m})$. NLRP3, NLR pyrin family domain containing 3; ESCC, esophageal squamous cell carcinoma. 
(Fig. 4H and I), demonstrating that NLRP3 promotes cell proliferation. Consistently, the wound-healing capability of the cells was also strongly increased in the EC9706 $(\mathrm{P}=0.045)$ and KYSE-510 ( $\mathrm{P}=0.021)$ cells following NLRP3 overexpression (Fig. 6A-D). Furthermore, NLRP3 upregulation increased the number of invasive cells in the EC9706 $(\mathrm{P}<0.0001)$ and KYSE-510 cell lines $(\mathrm{P}=0.0005)$, and enhanced tumor cell migration in the EC9706 $(\mathrm{P}<0.0001)$ and KYSE-510 $(\mathrm{P}<0.0001)$ cell lines (Fig. 6E-H). Overall, the present results demonstrated that NLRP3 is positively correlated with tumor progression by promoting cell proliferation, migration and invasion.

\section{Discussion}

Inflammasomes have been reported to play an important role in the progression of human cancer (21). The NLR pyrin family domain containing 3 (NLRP3) inflammasome has been shown to have both beneficial and adverse effects in multiple tumor types $(22,23)$. Allen et al found that the NLRP3 inflammasome could suppress colitis-associated carcinoma development (24), whereas Huang et al demonstrated that NLRP3 inflammasome promoted the development of head and neck squamous cell carcinoma (25). Similarly, Li et al found that the NLRP3 inflammasome accelerated the proliferation of epithelial cells and gastric cancer carcinogenesis (26). A study concerning oral cavity squamous cell carcinoma also showed that NLRP3 and interleukin (IL)-1 $\beta$ not only influenced poor overall and disease-specific survival but also were correlated with disease-free survival (27). However, the effect of the NLRP3 inflammasome on esophageal squamous cell carcinoma (ESCC) progression is unclear.

The present results showed that the mRNA levels of the components of the NLRP3 inflammasome [NLRP3, apoptosis-associated speck-like protein containing a CARD $(A S C)$, caspase-1 and $I L-1 \beta$ ] were all elevated in human ESCC tissues, as compared with those of adjacent non-cancerous tissues, although the degree of elevation varied between patients. Following the evaluation of the pathological characteristics of each patient, it was found that the high NLRP3 protein expression was associated with TNM stage and T category, but not with patient lymph node status, metastasis status, sex or age. Of note, a higher expression of NLRP3 was observed in patients with a higher pathological stage (III-IV vs. I-II). These data indicate that patients with a high NLRP3 expression may have a more malignant clinical phenotype.

To obtain a further understanding of the correlation of the NLRP3 with ESCC progression, the biological function of NLRP3 was assessed in vitro. It was found that the knockdown or overexpression of NLRP3 could markedly abolish or promote cell migration and invasion and decrease or increase cell mobility, respectively. These results suggest that NLRP3 inflammasome-mediated inflammation contributes to the development and progression of ESCC. Therefore, targeting NLRP3 may be an effective strategy for treating NLRP3-mediated diseases, such as ESCC.

This study, however, had several limitations. The upregulated NLRP3 inflammasome was only detected in some but not all ESCC patients. Further investigation could help clarify the reason for this apparent inconsistency. Alternatively, NLRP3 inflammasome undergoes post-translational revision.
Therefore, the phosphorylation or ubiquitination of NLRP3 may also affect inflammasome activation (28).

In conclusion, it was found in the present study that the NLRP3 inflammasome is upregulated in ESCC tissues and its activation is significantly associated with Ki-67 levels, T category and TNM stage. The NLRP3 inflammasome can stimulate ESCC proliferation, migration and invasion in vitro. Additional research is required to better understand the modulation of NLRP3 expression and target it accordingly.

\section{Acknowledgements}

The authors would like to thank Assistant Professor Xinshou Ouyang (Yale University, New Haven, Connecticut, CT, USA) for donating the pcDNA-3.1(+)-NLRP3 and pcDNA-3.1(+) vector plasmids.

\section{Funding}

The present study was sponsored by the National Natural Science Foundation in China (grant no. U1704282).

\section{Availability of data and materials}

This article included all study data.

\section{Authors' contributions}

All authors contributed equally in the present study. YHW, SNH and LRZ designed the study. SY, JJY, SGL and CZH carried out the experiments and analyzed the data. JXM analyzed the data. NH carried out the western blot analysis. TLF and XNL contributed to tissue collection. All authors read and approved the manuscript and agree to be accountable for all aspects of the research in ensuring that the accuracy or integrity of any part of the work are appropriately investigated and resolved.

\section{Ethics approval and consent to participate}

The Ethics Committee of First Clinical Hospital of Zhengzhou University (Zhengzhou, Henan, China) approved this study, and all patients provided informed consent.

\section{Patient consent for publication}

Not applicable.

\section{Competing interests}

The authors declare that they have no competing interests.

\section{References}

1. Bray F, Ferlay J, Soerjomataram I, Siegel RL, Torre LA and Jemal A: Global cancer statistics 2018: GLOBOCAN estimates of incidence and mortality worldwide for 36 cancers in 185 countries. CA Cancer J Clin 68: 394-424, 2018.

2. Napier KJ, Scheerer M and Misra S: Esophageal cancer: A review of epidemiology, pathogenesis, staging workup and treatment modalities. World J Gastrointest Oncol 6: 112-120, 2014. 
3. Chen W, Zheng R, Baade PD, Zhang S, Zeng H, Bray F, Jemal A, Yu XQ and He J: Cancer statistics in China, 2015. CA Cancer J Clin 66: 115-132, 2016.

4. Mimura K, Yamada L, Ujiie D, Hayase S, Tada T, Hanayama H, Thar Min AK, Shibata M, Momma T, Saze Z, et al: Immunotherapy for esophageal squamous cell carcinoma: A review. Fukushima J Med Sci 64: 46-53, 2018

5. van Hagen P, Hulshof MC, van Lanschot JJ, Steyerberg EW, van Berge Henegouwen MI, Wijnhoven BP, Richel DJ, Nieuwenhuijzen GA, Hospers GA, Bonenkamp JJ, et al: Preoperative chemoradiotherapy for esophageal or junctional cancer. N Engl J Med 366: 2074-2084, 2012.

6. Grivennikov SI, Greten FR and Karin M: Immunity, inflammation, and cancer. Cell 140: 883-899, 2010.

7. Broz P and Monack DM: Molecular mechanisms of inflammasome activation during microbial infections. Immunol Rev 243: 174-190, 2011.

8. Gross O, Thomas CJ, Guarda G and Tschopp J: The inflammasome: An integrated view. Immunol Rev 243: 136-151, 2011.

9. Fink SL and Cookson BT: Apoptosis, pyroptosis, and necrosis: Mechanistic description of dead and dying eukaryotic cells. Infect Immun 73: 1907-1916, 2005.

10. Karki R, Man SM and Kanneganti TD: Inflammasomes and cancer. Cancer Immunol Res 5: 94-99, 2017.

11. Zitvogel L, Kepp O, Galluzzi L and Kroemer G: Inflammasomes in carcinogenesis and anticancer immune responses. Nat Immunol 13: 343-351, 2012.

12. Okamoto M, Liu W, Luo Y, Tanaka A, Cai X, Norris DA, Dinarello CA and Fujita M: Constitutively active inflammasome in human melanoma cells mediating autoinflammation via caspase-1 processing and secretion of interleukin-1beta. J Biol Chem 285: 6477-6488, 2010.

13. Wang Y, Kong H, Zeng X, Liu W, Wang Z, Yan X, Wang H and Xie W: Activation of NLRP3 inflammasome enhances the proliferation and migration of A549 lung cancer cells. Oncol Rep 35: 2053-2064, 2016.

14. Wang $\mathrm{H}$, Wang $\mathrm{Y}, \mathrm{Du} \mathrm{Q}, \mathrm{Lu} \mathrm{P}, \mathrm{Fan} \mathrm{H}, \mathrm{Lu} \mathrm{J}$ and $\mathrm{Hu} \mathrm{R}$ : Inflammasome-independent NLRP3 is required for epithelial-mesenchymal transition in colon cancer cells. Exp Cell Res 342: 184-192, 2016.

15. Bruchard M, Mignot G, Derangère V, Chalmin F, Chevriaux A, Végran F, Boireau W, Simon B, Ryffel B, Connat JL, et al: Chemotherapy-triggered cathepsin $\mathrm{B}$ release in myeloid-derived suppressor cells activates the Nlrp3 inflammasome and promotes tumor growth. Nat Med 19: 57-64, 2013.

16. Wei Q, Mu K, Li T, Zhang Y, Yang Z, Jia X, Zhao W, Huai W, Guo P and Han L: Deregulation of the NLRP3 inflammasome in hepatic parenchymal cells during liver cancer progression. Lab Invest 94: 52-62, 2014.
17. Chen LC, Wang LJ, Tsang NM, Ojcius DM, Chen CC, Ouyang CN, Hsueh C, Liang Y, Chang KP, Chen CC and Chang YS: Tumour inflammasome-derived IL- $1 \beta$ recruits neutrophils and improves local recurrence-free survival in EBV-induced nasopharyngeal carcinoma. EMBO Mol Med 4: 1276-1293, 2012.

18. Pirker R, Pereira JR, von Pawel J, Krzakowski M, Ramlau R, Park K, de Marinis F, Eberhardt WE, Paz-Ares L, Störkel S, et al: EGFR expression as a predictor of survival for first-line chemotherapy plus cetuximab in patients with advanced non-small-cell lung cancer: Analysis of data from the phase 3 FLEX study. Lancet Oncol 13: 33-42, 2012.

19. Livak KJ and Schmittgen TD: Analysis of relative gene expression data using real-time quantitative PCR and the 2(-Delta Delta $\mathrm{C}(\mathrm{T})$ ) method. Methods 25: 402-408, 2001.

20. Guanen Q, Junjie S, Baolin W, Chaoyang W, Yajuan Y, Jing L, Junpeng L, Gaili N, Zhongping W and Jun W: miR-214 promotes cell metastasis and inhibits apoptosis of esophageal squamous cell carcinoma via PI3K/AKT/mTOR signaling pathway. Biomed Pharmacother 105: 350-361, 2018.

21. de Martel C and Franceschi S: Infections and cancer: Established associations and new hypotheses. Crit Rev Oncol Hematol 70: 183-194, 2009.

22. He Q, Fu Y, Tian D and Yan W: The contrasting roles of inflammasomes in cancer. Am J Cancer Res 8: 566-583, 2018.

23. Moossavi M, Parsamanesh N, Bahrami A, Atkin SL and Sahebkar A: Role of the NLRP3 inflammasome in cancer. Mol Cancer 17: 158, 2018.

24. Allen IC, TeKippe EM, Woodford RM, Uronis JM, Holl EK, Rogers AB, Herfarth HH, Jobin C and Ting JP: The NLRP3 inflammasome functions as a negative regulator of tumorigenesis during colitis-associated cancer. J Exp Med 207: 1045-1056, 2010.

25. Huang CF, Chen L, Li YC, Wu L, Yu GT, Zhang WF and Sun ZJ: NLRP3 inflammasome activation promotes inflammation-induced carcinogenesis in head and neck squamous cell carcinoma. J Exp Clin Cancer Res 36: 116, 2017.

26. Li S, Liang X, Ma L, Shen L, Li T, Zheng L, Sun A, Shang W, Chen $\mathrm{C}$, Zhao W and Jia J: miR-22 sustains NLRP3 expression and attenuates $\mathrm{H}$. pylori-induced gastric carcinogenesis. Oncogene 37: 884-896, 2018.

27. Mantovani A, Romero P, Palucka AK and Marincola FM: Tumour immunity: Effector response to tumour and role of the microenvironment. Lancet 371: 771-783, 2008.

28. Juliana C, Fernandes-Alnemri T, Kang S, Farias A, Qin F and Alnemri ES: Non-transcriptional priming and deubiquitination regulate NLRP3 inflammasome activation. J Biol Chem 287: 36617-36622, 2012.

This work is licensed under a Creative Commons Attribution-NonCommercial-NoDerivatives 4.0 International (CC BY-NC-ND 4.0) License. 